\title{
Agricultural practice negatively affects soil microbial diversity and nitrogen functional genes comparing to adjacent native forest soils
}

\author{
Tiehang $\mathrm{Wu}^{1}$, Michael Sabula ${ }^{1}$, Holli Milner ${ }^{1}$, Gary Strickland ${ }^{1}$, and Gan Liu ${ }^{1}$ \\ ${ }^{1}$ Georgia Southern University
}

December 6, 2021

\begin{abstract}
Soil microbial diversity and community are determined by anthropogenic activities and environmental conditions, which greatly affect the functioning of ecosystem. We investigated the soil bacterial diversity, communities, and nitrogen (N) functional genes with different disturbance intensity levels from crop, transition, to forest soils at three locations in the coastal region of Georgia, USA. Illumina high-throughput DNA sequencing based on bacterial 16S rRNA genes were performed for bacterial diversity and community analyses. Nitrifying (AOB amoA) and denitrifying (nirK) functional genes were further detected using quantitative PCR (qPCR) and Denaturing Gradient Gel Electrophoresis (DGGE). Soil bacterial community structure determined by Illumina sequences were significantly different between crop and forest soils ( $\mathrm{p}<0.01$ ), as well as between crop and transition soils $(\mathrm{p}=0.01)$. However, there is no difference between transition and forest soils. Compared to less disturbed forest, agricultural practice significantly decreased soil bacterial richness and Shannon diversity. Soil $\mathrm{pH}$ and nitrate contents together contributed highest for the observed different bacterial communities (Correlations $=0.381$ ). Two OTUs (OTU5, OTU8) belonging to Acidobacteriales species decreased in crop soils, however, agricultural practices significantly increased an OTU (OTU4) of Nitrobacteraceae. The relative abundance of AOB amoA gene was significantly higher in crop soils than in forest and transition soils. Distinct grouping of soil denitrifying bacterial nirK communities was observed and agricultural practices significantly decreased the diversity of nirK gene compared to forest soils. Anthropogenic effects through agricultural practices negatively affecting the soil bacterial diversity, community structure, and $\mathrm{N}$ functional genes.
\end{abstract}

\section{Agricultural practice altering soil microbial diversity and nitrogen functional genes comparing to adjacent native forest soils}

Tiehang $\mathrm{Wu}^{*}$, Michael Sabula, Holli Milner, Gary Strickland, and Fan of Liu

Department of Biology, Georgia Southern University, Statesboro, GA 30460-8042, USA

* Address correspondence to Tiehang Wu, twu@georgiasouthern.edu

Running title: Agriculture practice altering soil microbial diversity

Abstract: Soil microbial diversity and community are determined by anthropogenic activities and environmental conditions, which greatly affect the functioning of ecosystem. We investigated the soil bacterial diversity, communities, and nitrogen $(\mathrm{N})$ functional genes with different disturbance intensity levels from crop, transition, to forest soils at three locations in the coastal region of Georgia, USA. Illumina highthroughput DNA sequencing based on bacterial 16S rRNA genes were performed for bacterial diversity and community analyses. Nitrifying (AOB amo A) and denitrifying (nir K) functional genes were further detected using quantitative PCR (qPCR) and Denaturing Gradient Gel Electrophoresis (DGGE). Soil bacterial community structure determined by Illumina sequences were significantly different between crop and forest soils $(\mathrm{p}<0.01)$, as well as between crop and transition soils $(\mathrm{p}=0.01)$. However, there is no difference between transition and forest soils. Compared to less disturbed forest, agricultural practice significantly 
decreased soil bacterial richness and Shannon diversity. Soil $\mathrm{pH}$ and nitrate contents together contributed highest for the observed different bacterial communities (Correlations $=0.381$ ). Two OTUs (OTU5, OTU8) belonging to Acidobacteriales species decreased in crop soils, however, agricultural practices significantly increased an OTU (OTU4) of Nitrobacteraceae. The relative abundance of AOBamo A gene was significantly higher in crop soils than in forest and transition soils. Distinct grouping of soil denitrifying bacterialnir $\mathrm{K}$ communities was observed and agricultural practices significantly decreased the diversity of nir $\mathrm{K}$ gene compared to forest soils. Anthropogenic effects through agricultural practices negatively affecting the soil bacterial diversity, community structure, and $\mathrm{N}$ functional genes.

Keywords: Agricultural practice, microbial diversity; microbial community; nitrification, denitrification, nitrogen functional genes.

\section{INTRODUCTION}

Soil microorganisms, which are critical to many of the biological, chemical, physical processes, are the most abundant and diverse group of organisms in soils on earth. It is estimated that one gram of soil contains of about $10^{4}-10^{6}$ distinct genomes (Torsvik and Goksoyr 1978, Gans et al. 2005, Wu et al. 2008). Soil microorganisms play important roles in terrestrial ecosystems, and greatly affect soil ecosystem functions. Because soil microbiome regulates biogeochemical cycling of macronutrients and micronutrients such as carbon, nitrogen, copper, and iron, as well as other elements vital for the growth of plants and animal life, they greatly affect climate change, plant and soil health. Anthropogenic activities especially agricultural practices greatly affect the soil microbial diversity, community structure, and nitrogen (N) functional genes (Bevivino et al. 2014, Goss-Souza et al. 2019). We are in the processes for understanding and predicting the human impact on soil microbiomes and their ecosystem functions, providing fundamental evidence for climate change and soil health, and presenting a magnificent challenge and most important opportunity towards the most challenging problems facing our planet.

Soil microbes exert strong influence over the soil N cycle, playing critical roles in both nitrification and denitrification (Le Roux et al. 2013). The nitrification and denitrification processes which are the key processes of $\mathrm{N}$ cycling are regulated by a variety of $\mathrm{N}$ functional genes (Levy-Booth et al. 2014, Ouyang et al. 2018). In the process of nitrification, autotrophic microorganisms, both archaea and bacteria play roles in the process. Two genes in archaea and bacteria respectively related to ammonia oxidation to nitrite: ammonia oxidizing (amo ) genes from archaea AOA amo A and from bacteria AOBam oA, are the rate-limiting factor in nitrification, therefore are critical for the assessment of nitrification potential and communities (Szukics et al. 2012). The nitrite oxidized from ammonia is further oxidized to nitrate $\left(\mathrm{NO}_{3}{ }^{-}\right)$through nitrite oxidoreductase genes (nrx A and $\left.n r x \mathrm{~B}\right)$ of nitrite oxidizers, such as nitrite-oxidizing bacteria (NOB), to finish the nitrification process (Daims et al. 2016). Heterotrophic denitrification is a serial reduction process of reducing $\mathrm{NO}_{3}{ }^{-}$to $\mathrm{N}_{2}$ gas through serial intermediate products. First, $\mathrm{NO}_{3}{ }^{-}$is reduced nitrite $\left(\mathrm{NO}_{2}{ }^{-}\right)$regulated by nitrate reductase (nar ); second, $\mathrm{NO}_{2}{ }^{-}$to nitric oxide (NO) by nitrite reductase (nir ); third, $\mathrm{NO}$ to nitrous oxide $\left(\mathrm{N}_{2} \mathrm{O}\right)$ through nitric oxide reductase (nor ); and finally, $\mathrm{N}_{2} \mathrm{O}$ to $\mathrm{N}_{2}$ gas regulated by nitrous oxide reductase (nos), respectively. The incomplete oxidation of $\mathrm{NH}_{4}{ }^{+}$by AOB forms intermediate product $\mathrm{NH}_{2} \mathrm{OH}$, which could be converted to $\mathrm{N}_{2} \mathrm{O}$ through hydroxylamine oxidation (HAO) process. Autotrophic nitrifier is also involved in the $\mathrm{N}_{2} \mathrm{O}$ emission, which is the pathway of nitrification by oxidizing ammonia $\left(\mathrm{NH}_{3}\right)$ to $\mathrm{NO}_{2}{ }^{-}$, followed by the reduction of $\mathrm{NO}_{2}{ }^{-}$to nitric oxide (NO) and further to $\mathrm{N}_{2} \mathrm{O} . \mathrm{N}_{2} \mathrm{O}$ can be emitted as a byproduct of ammonia oxidation as an intermediate product of heterotrophic denitrification. Soil chemical, physical, and microbial characteristics closely affect the $\mathrm{N}$ cycling processes thus determine the $\mathrm{N}_{2} \mathrm{O}$ emission in soil ecosystems. Soil moisture such as Water Filled Pore Space (WFPS) plays important roles in the mitigation of $\mathrm{N}_{2} \mathrm{O}$ emission. With the decreasing soil oxygen $\left(\mathrm{O}_{2}\right)$ concentration, soil $\mathrm{N}_{2} \mathrm{O}$ concentration increased exponentially in well-structured agricultural soil (Song et al. 2019). Four orders of magnitude higher $\mathrm{N}_{2} \mathrm{O}$ was measured in the wettest soil (100\% WFPS) compared with the dry soil (40\% WFPS) in tested peat, clay and loamy sand soils (Pihlatie et al. 2004). Denitrification-derived $\mathrm{N}_{2} \mathrm{O}$ emission could be triggered with application of organic matter with high contents of labile $\mathrm{C}$, however, substantially lower $\mathrm{N}_{2} \mathrm{O} /\left(\mathrm{N}_{2} \mathrm{O}+\mathrm{N}_{2}\right)$ production ratio and hence $\mathrm{N}_{2} \mathrm{O}$ emission was generated in soils with 
low $\mathrm{NO}_{3}{ }^{-}$contents (Senbayram et al. 2012).

Soil microbiome also plays important roles in soil functioning and maintaining soil health, including the capability of soil microbiome to control diseases caused by soilborne pathogens. Relationship between microbial community structure and the occurrence of soilborne disease is not completely understood, but crop management practices have been widely reported influencing ecological processes that affect microbial communities involved in the suppression of soilborne disease development and incidence (Vanbruggen 1995, Burton et al. 2010, Chellemi et al. 2012). Through the proper manipulation of the microbial community structure, the population of antagonistic microorganisms can be altered thus decrease the amounts of soilborne pathogens (Vanbruggen 1995, Chellemi et al. 2012).

Agricultural practices have been widely reported in altering soil microbial diversity and community (Wu et al. 2008, Bevivino et al. 2014, de Graaff et al. 2019), especially in the conversion from forest to agriculture (Upchurch et al. 2008, Rodrigues et al. 2013, Goss-Souza et al. 2019, Lammel et al. 2021). The consequence of shifting in microbial diversity and community greatly affect the ecosystem functions. Nitrification and denitrification in regulating soil microbiomes for $\mathrm{N}_{2} \mathrm{O}$ emission and $\mathrm{NO}_{3}{ }^{-}$leaching are critical processes for climate change effects on the environment and human welfare. The agricultural practices change $\mathrm{N}$ cycling of nitrification and denitrification may also affect the soil microbiome and $\mathrm{N}$ forms, thus potentially affect soilborne diseases. Human activities and inputs greatly affect soil chemical and biochemical composition as well as bacterial community. A more stable soil chemical and biological composition was observed in soils subjected to low human inputs than in those with high human input, which is likely to be one of main drivers of biodiversity changes (Bevivino et al., 2014). We focused on the vegetation types and soil disturbance intensity levels, especially the transition from forest to crop soils, on soil microbiomes in regulating microbial diversity, community structure, and $\mathrm{N}$ cycling and their potential on microbial-mediated nitrous oxide $\left(\mathrm{N}_{2} \mathrm{O}\right)$ emission for global warming, nitrate $\left(\mathrm{NO}_{3}{ }^{-}\right)$leaching for groundwater pollution, as well as microbial community in the mitigation of soilborne diseases for soil health. Agricultural practices altering soil bacterial community and functional genes involved in $\mathrm{N}$ cycling processes were explored, in order to understand their effects on fundamental knowledge in maintaining healthy soils, sustaining plant productivity, and enhancing water and air quality.

\section{Materials and Methods}

\subsection{Study site}

The study was carried on three sampling locations located in Southeast Georgia, including 1) Acacia (A) Farm (Latitude $32^{\circ} 34.784 \mathrm{~N}$, Longitude $\left.82^{\circ} 32.313 \mathrm{~W}\right)$, 2) Honeydew (H) Farm (32 $\left.32.354 \mathrm{~N}, 81^{\circ} 50.053 \mathrm{~W}\right)$, and 3) Strickland (S) Farm" (32 $\left.19.231 \mathrm{~N}, 81^{\circ} 41.554 \mathrm{~W}\right)$. At each of the location, three sites with different vegetation types and disturbance intensity levels. The first site, site one (1) is representative of a conventional tomato (Lycopersicon esculentum ) crop field, defined as highly disturbed agricultural crop production (C) soil. The second site is a transitional region, where a secondary successional event is occurring (dominated by Andropogon spp.) and defined as moderate disturbed transitional environment (T). The third site is representative of a recently undisturbed forest habitat, containing both deciduous hardwood (Quercus spp.). and coniferous pine forests (Pinus spp.) and defined as less-disturbed native forests (F). At a location, sampling sites were no more than 100 meters apart. Physical and chemical soil properties including soil organic (\%), $\mathrm{NO}_{3}^{-}, \mathrm{P}, \mathrm{Mg}, \mathrm{Ca}$, soil $\mathrm{pH}$, and cation exchange-capacity, were determined by Waters Agricultural Laboratories, Inc. Camilla, GA, and soil ammonium was determined at Georgia Southern University by extracting soils with $2 \mathrm{M} \mathrm{KCl}$ and followed with the salicylate method (Nelson 1983).

\subsection{Sample collection and DNA extraction}

Soil samples were collected from there locations (A, H, and S) under three sites with different vegetation types and disturbance intensity levels $(\mathrm{C}, \mathrm{T}$, and $\mathrm{F})$. Three replicates of the samples were collected from each of the three vegetation types of three different locations, thus a total of 27 samples were obtained. At each site, one approximately $6 \times 50$-meter plot was randomly selected, and a grid with 30-centimeter intervals was established on each plot. We collected soil samples from total of 30 generated coordinates and 
used a stratified random sampling regime. Total of thirty soil cores $(3.4 \mathrm{~cm}$ diameter; $10 \mathrm{~cm}$ deep $)$ from the rhizosphere of each site were collected with a core sampler and hand mixed in a single sterile plastic bag. We mixed ten soils cores into a single sample, thus each site yielding 3 samples. A grand total of 27 samples were collected with three sites at each of the tree locations. The DNA was extracted using PowerSoil DNA Isolation Kit from each sample (Mo Bio Laboratories, Inc., Carlsbad, CA).

\subsection{Total bacterial DNA quantification}

A NanoDrop spectrophotometer, ND-1000 (NanoDrop Technologies, Wilmington, DE) was used to quantify total DNA of each sample. Soil bacterial DNA was quantified by Real-time quantitative-PCR (Q-PCR) as the indicator of relative soil bacterial abundance (Fierer et al. 2005). The Q-PCR was performed in a the QuantStudio 6 Flex Real-Time PCR System (Life Technologies, Carlsbad, CA, USA) using the conditions as described previously (Wu et al. 2015). In brief, $16 \mathrm{~S}$ rRNA gene was amplified with the primers 27F (5'-AGAGTTTGATCMTGGCTCAG-3') and 355R (5'-GCTGCCTCCCGTAGGAGT-3') for bacterial quantification. We extracted DNA from the pure culture of Micrococcus lutus (Item \# 155160 from Carolina Biological Supply Company, Burlington, NC, USA) as the standard DNA. The standards with serial diluted DNA concentration extracted from pure culture was quantified using NanoDrop spectrophotometer, ND-1000 (NanoDrop Technologies, Wilmington, DE).

\subsection{Illumina sequencing}

We used the NanoDrop ND-1000 UV-Vis Spectrophotometer (NanoDrop Technologies, Wilmington, DE, USA) to quantify the above extracted DNA. Primers 27F (5'-

AGAGTTTGATCMTGGCTCAG-3') and 355R (5'- GCTGCCTCCCGTAGGAGT-3') were used to amplify the V1-V2 hyper variable region of the $16 \mathrm{~S}$ rRNA bacterial gene. DNA sequencing was conducted at University of Georgia Genomics and Bioinformatics Cores (Athens, Georgia, USA), using the MiSeq platform (Illumina, Inc., USA). QIIME software was selected for the purpose of integrating the original FASTQ format sequencing data (Caporaso et al. 2010). The USEARCH tool (version 7.0; http://drive5.com/usearch/) was used to vet and remove chimeric sequences. The operational taxonomic unit (OTU) partition threshold was identified at a $97 \%$ sequence similarity of classification results, which was subsequently used for the calculation of bacterial community diversity and relative abundance. To obtain species classification data corresponding to each OTU, the 16S Metagenomics from Illumina Sequence Hub (Illumina, Inc., San Diego, CA USA) was applied to analyze DNA from amplicon sequencing of prokaryotic $16 \mathrm{~S}$ small subunit rRNA genes.

2.5 Quantitative PCR (qPCR) and Denaturing Gradient Gel Electrophoresis (DGGE) for N functional genes

Quantitative PCR amplification of selected nitrification and denitrification genes (AOB amo A and nir K genes) with corresponding primers (Wu et al. 2020) was performed using the QuantStudio 6 Flex RealTime PCR System (Life Technologies, Carlsbad, CA, USA). The fluorescent dye SYBR-Green I which binds to double-stranded DNA was applied to quantify the relative abundance of nitrification AOB amo A and denitrification nir K genes. Each of the PCR mixtures contained $12.5 \mu \mathrm{L}$ of $2 \times$ GoTaq® Colorless Master Mix (Promega, USA), $0.5 \mu \mathrm{L}$ of $10 \mu \mathrm{M}$ forward and reverse primer, $1 \mu \mathrm{L}$ BSA, $2 \mu \mathrm{L}$ SYBR $\mathbb{R}$ of $1 \times, 6 \mu \mathrm{L}$ of nuclease-free water, and $2 \mu \mathrm{L}$ of DNA template, which make the recommended $25 \mu \mathrm{L}$ protocol. To control for mechanical and technical errors, the Q-PCR of each sample was run in triplicate, and the mean of all three DNA quantities was used for statistical analysis.

The GC clamp was added to the corresponding primer position for DGGE analysis. Amplified gene products (AOB amo A and nir $\mathrm{K}$ ) were run on $8 \%(\mathrm{w} / \mathrm{v})$ acrylamide with a linear chemical gradient ranging from 40\%-70\% using a DGGEK-1001 Cipher DGGE Kit (C.B.S. Scientific, Del Mar, CA, USA) and obtained DGGE band patterns were exported for further nonparametric multivariate analyses of soil microbial and $\mathrm{N}$ functional gene communities as described previously (Wu et al. 2020).

2.6 Link soil microbial community structure with environmental factors 
We used PRIMER-E including PERMANOVA+ statistical software (PRIMER-E, Plymouth, UK) to generate soil bacterial and $\mathrm{N}$ functional gene similarity matrices of each sample from three different locations and three different vegetation types with different disturbance intensity levels. Bio-Env function and Principal Coordinates Analysis (PCO) with Spearman's correlations of variables with the PCO axes of PRIMER-E were used to correlate the environmental factors with the similarity matrix (Wu et al. 2015, Wu et al. 2020).

2.7 Statistical analysis of operational taxonomic unit (OTUs) to test diversity and similarity

Univariate analysis of operational taxonomic unit (OTUs) by different fragment lengths or $97 \%$ sequence similarity was used to characterize diversity indices. Richness (S) was expressed as the total number of different OTUs identified. Diversity was calculated using the Shannon-Weiner (Weaver) index using the equation of Diversity $(\mathrm{H}): \mathrm{H}^{\prime}=-[?]\left(\mathrm{p}_{\mathrm{i}}\right)\left(\log _{\mathrm{e}} \mathrm{p}_{\mathrm{i}}\right)$, where pi is the proportion of an individual OTU relative to the sum of OTUs detected in a sample. Evenness was calculated by Pielou's evenness index using the equation of $\mathrm{J}^{\prime}=\mathrm{H}^{\prime} / \log (\mathrm{S})$. Univariate analyses of richness, richness and Shannon diversity indices were performed with JMP@ Pro 12.1.0 (SAS Institute Inc., USA). Cluster analysis was used to compare soil bacterial communities and $\mathrm{N}$ functional genes from there locations $(\mathrm{A}, \mathrm{H}$, and $\mathrm{S})$ under three sites with different vegetation types and disturbance intensity levels $(\mathrm{C}, \mathrm{T}$, and $\mathrm{F}$ ). The analysis of similarities (ANOSIM) procedure was applied to statistically discriminate the soil bacterial communities and $\mathrm{N}$ functional genes. The bacterial $16 \mathrm{~S}$ rDNA OTUs obtained from Illumina sequencing from there locations under three sites with different vegetation types and disturbance intensity levels were determined using the similarity percentages (SIMPER) procedure. PRIMER-E including PERMANOVA+ statistical software (Primer-E, Plymouth Marine Laboratory, UK) was applied for all nonparametric multivariate analysis procedures, including calculation of Bray-Curtis similarity matrices, cluster analysis, SIMPER analysis, and ANOSIM.

\section{Results}

\subsection{Soil Chemical Characteristics}

Although some of the soil chemical characteristics were significantly affected by different farms, different vegetation types and disturbance intensity levels greatly affect the soil chemical characteristics including soil $\mathrm{pH}$, soil organic matter (\%), nitrate, phosphorous, potassium, calcium concentration, and CEC (Table 1). Soil pH, soil nitrate, phosphorus, and calcium contents in forest soils were significantly lower than that in crop soils. Whereas soil organic matter (\%) was significantly higher in forest soils than in crop soils (Table $1)$.

\subsection{Soil bacterial diversity and abundance}

Total of 553,648 clean Illumina sequences and 1,587 OTUs were obtained from 27 samples (3 locations, 3 vegetation types, 3 replicates). The average sequence length from each sample ranges from $468-479 \mathrm{bp}$. The proteobacteria were most dominant phylum, followed by Acidiobacteria, Chlorofelexi, Cyanobacteria, Planctomycetales, Patescibacteria and Actinobacteria etc. (Figure 1). The relative abundance of Acidiobacteria was highest in forest and lowest in crop soils, and was significantly higher in forests soils than in transition, as well as in transition than in crop soils (Figure 2). However, the relative abundance of Proteobacteria was significantly increased in crop soils compared with transition and forest soils (Figure 2).

Compared with forest soils, agricultural practices in the crop soils significantly decreased soil bacterial richness $(\mathrm{p}=0.04)$ and Shannon diversity $(\mathrm{p}=0.02)$, but no effect on the evenness was observed (Table 2$)$. There were no location or vegetation and location interaction effects for all three diversity indices (Table 2).

3.3 Soil bacterial community and relationship with environmental factors

Soil bacterial community structure was distinguished by vegetation types (Figure 3A and B). Cluster and Analysis of Similarity (ANOSIM) indicated that crop and forest soils had significantly different soil bacterial community structure $(\mathrm{p}=0.004)$. Soil bacterial communities in crop soils also significantly different from those in transition soils $(\mathrm{p}=0.011)$. However, there was no significant soil bacterial community structure 
difference between transition and forest soils $(\mathrm{p}=0.265)$. Soil $\mathrm{pH}$ and nitrate contents together contributed to highest for the observed different bacterial community (Correlation $=0.381)$.

Similarity percentage breakdown (SIMPER) analysis of bacterial contribution $\%$ to each vegetation based on Illumina sequencing OTUs revealed that an uncultured bacterium OTU 1 belonging to Xanthobacteraceae dominated all three vegetation types with different disturbance intensity levels (Table 3). However, three OTUs (OUT5, OTU8, and OTU4) among the top five ranking in each vegetation type contributed differently to three vegetation types (Table 3). The relative abundance of two Acidobacteriales species (OTU5, OTU8) were decreased by agricultural practices in crop soils, which is consistent with observed high pH (Figure 4A). However, agricultural practices significantly increased Nitrobacteraceae OTU (OTU4), which is a potential bacterial species for nitrification (Figure 4B).

\subsection{Soil N functional genes and relationship with environmental factors}

The relative abundance of AOB amo A gene was significantly higher in crop soils than in forest and transition soils (Table 4). No significant difference was observed for the relative abundance ofnir $\mathrm{K}$ gene among the three different vegetation types (Table 4).

There were no differences for the biodiversity indices for AOBamo A genes. However, the richness and diversity of nir $\mathrm{K}$ gene were significantly higher in forest soil than in crop and transition soils (Table 5), and their community structure was significantly differentiated by the three vegetation types (ANOSIM p = 0.001), not by the farms (ANOSIM p = 0.296) (Fig. $5 \mathrm{~A}$ and B). Soil organic matter $\%$ and soil $\mathrm{pH}$ together contributed highest for the observed different nir $\mathrm{K}$ functional gene community (Correlation $=0.443$ ). There was no significant difference of the diversity of denitrifying bacteria determined by nir $\mathrm{S}$ gene and all the environmental factors contributed less than 0.1 as correlation ecoefficiency.

\section{Discussion}

Our study aimed to understand how agricultural practices affect soil microbial diversity, community structure and functional genes, as well as what are the environmental factors affecting the microbial distribution between and among different vegetation types and disturbance intensity environments. Clearly understanding soil microbiomes and their ecosystem functions will provide great potential to gauge the health of soil ecosystems in regulation of $\mathrm{N}_{2} \mathrm{O}$ emission for global warming and $\mathrm{NO}_{3}{ }^{-}$leaching for ground water contamination, as well as soil microbiomes and $\mathrm{N}$ forms to suppress soilborne diseases.

Agricultural practices on the composition changes of soil bacterial community were noticeably determined in this study. At the phylum level, the relative abundance of Acidiobacteria was highest in forest soils, followed by the transition soils, and which was lowest in crop soils (Figure 2). At the OTU level, we further observed that the relative abundance of two OTUs (OTU5 and OTU8), both belonging to the Acidiobactria, were following the same pattern (Figure 4A). The phylum Acidiobactria was consider as acidophilic, and environmental factors such as $\mathrm{pH}$ and nutrients have been seen to drive Acidobacteria dynamics (Fierer et al. 2007, Jones et al. 2009, Kielak et al. 2016). Forest soil had a significant lower soil pH than crop soils did (Table 1), which supported the observed higher relative abundance of Acidiobacteria in forest than in crop soils. The results are also consistent with the observation in the conversion of the Amazon rainforest to agricultural, which also confirmed a large proportional decrease from an average of $21.0 \%$ in forest to $13.4 \%$ in pasture by the phylum of Acidiobacteria (Rodrigues et al. 2013). Beyond preferring acidic soil condition, Acidiobacteria are known oligotrophs (Eichorst et al. 2007), which may be not limited by the organic matter \% in the soil ecosystems of this study. Soil pH and nitrate contents together, but not including soil organic matter \%, contributed to highest for the observed different bacterial community (Correlation $=0.381$ ). We also found that agricultural practices significantly increased an OTU (OTU4) which belong to the family of Nitrobacteraceae (Figure 4B). Nitrification is brought about by two distinct physiological groups of Gram-negative chemoautotrophic bacteria belonging to Nitrobacteraceae. The bacteria of the Nitrobacteraceae family including potential bacterial species for nitrification, which derive their energy from oxidizing ammonia to nitrite, or by oxidizing nitrite to nitrate (Schmidt et al. 2002). Using Q-PCR, we also discovered significantly higher nitrification functional gene AOBamo A in crop than in forest soils 
(Table 4), which protentional supported the observed different composition of the OTU which belongs to the nitrification related family of Nitrobacteraceae. Lower nitrification rate in acidic forest soils was reported due to $\mathrm{pH}$ related factor (Nugroho et al. 2007). In a study on Tennessee tulip-poplar forest, the low initial population sizes of nitrifiers were proved probably to be the most important factor responsible for the low nitrification rate (Jha et al. 1996). Increased nitrification rate was also reported positively related to the emission of soil nitrous oxide at a global scale (Li et al. 2020).

Environmental perturbations such as agricultural intensification have been reported altering soil biodiversity and consequently affecting ecosystem functions (de Graaff et al. 2019). Our study also confirmed that transition from forest to agricultural soil, perturbations in agricultural practices significantly decrease soil bacterial richness and Shannon diversity. The lower Shannon diversity in crop than in forest soil is consistent to the previous study that forest soils would have higher Shannon diversity due to fewer disturbances (Jangid et al. 2008), whereas agricultural practices significantly decreased Shannon diversity due to the highly perturbations during the agricultural practices (Rodrigues et al. 2013, de Graaff et al. 2019).

Soil pH and nitrate content contribute to observed soil bacterial community in our study. Soil pH determining bacterial community was widely reported and the effects of soil $\mathrm{pH}$ as a primary determinant of microbial community composition and diversity have been widely documented in previous studies (Lauber et al. 2009, Rousk et al. 2010). The diversity and richness of soil bacterial communities were proved to be differed by ecosystem type, and these differences could largely be explained by soil $\mathrm{pH}$ based on a study using 98 soil samples from across North and South America (Fierer and Jackson 2006). Bacterial structure was also reported mainly affected by nitrate nitrogen ( $\mathrm{Li}$ et al. 2021). In our study, agricultural practices significantly increased soil $\mathrm{pH}$ and nitrate content in the transition from forest to crop soils (Table 1), which further proved that agricultural practices altered soil abiotic traits, thus affected soil microbiomes and their potential effects on ecosystem functions.

Soil organic matter $\%$ and soil $\mathrm{pH}$ together contributed highest to the observed different nir $\mathrm{K}$ functional gene community in our study (Correlation $=0.443$ ). Limited studies have examined how environmental factors affect the denitrification functional genes. In general, thenir K dinitrifers are heterotrophic, therefore organic matter may contribute to their metabolic pathway, which may explain a high contribution of soil organic matter $\%$ to observed difference ofnir $\mathrm{K}$ community under various vegetation types. The response of dinitrifiers to soil $\mathrm{pH}$ may be similar to other soil heterotrophs, which usually function best near neutrality(Cavigelli and Robertson 2001). Soil pH has been reported affecting the nitrification rate (Kyveryga et al. 2004). Forest soil with lower soil pH also performed lower nitrification rate (Nugroho et al. 2007). Furthermore, denitrifier diversity was closely related to the rates of nitrous oxide consumption in a terrestrial ecosystem, and denitrifier community composition alone can potentially influence in situ $\mathrm{N}_{2} \mathrm{O}$ production (Cavigelli and Robertson 2000, 2001). Land-use change due to agricultural intensification is one of the most significant anthropogenic activities that greatly affect soil microbial communities by altering edaphic variables (Geisen et al. 2019). A more stable soil chemical and biological composition was observed in soils subjected to low human inputs than in those with high human input, which is likely to be one of main drivers of biodiversity changes (Bevivino et al. 2014). We focused on how agricultural practices alter the microbial diversity, and the shifting in soil microbiomes are critical for their protentional roles in regulating $\mathrm{N}$ cycling and their effects including microbial-mediated nitrous oxide $\left(\mathrm{N}_{2} \mathrm{O}\right)$ emission for global warming, nitrate $\left(\mathrm{NO}_{3}{ }^{-}\right)$leaching for groundwater pollution, as well as microbial community in the mitigation of soilborne diseases for soil health.

Soil nitrogen and nitrogen forms have been intensively studied in relation to host nutrition and disease severity (Huber and Watson 1974). However, nitrogen forms affected soilborne diseases differently. $\mathrm{NO}_{3}{ }^{-}$ stabilizes rhizosphere fungal community in suppress Fusarium wilt disease (Gu et al. 2020). In contrast, using ammonium instead of nitrate has been reported in reduced incidence of the Southern blight disease (Jenkins and Averre 1986). We observed significant high $\mathrm{NO}_{3}{ }^{-}$contents in crop than in forest soils (Table 1), which may affect the development of soilborne disease, such as Southern blight (Sclerotium rolfsii) disease, and soil health for agricultural production (Jenkins and Averre 1986, Milner et al. 2019).

We found significant higher AOB amo A gene relative abundance (Table 4) and lower nir $\mathrm{K}$ richness and 
Shannon diversity (Table 5) in crop than in forest soils, suggesting agricultural practices potentially increase nitrification as well as negatively affect denitrification communities and processes. Higher nitrification rate has been reported relating to higher $\mathrm{N}_{2} \mathrm{O}$ to atmosphere and $\mathrm{NO}_{3}{ }^{-}$leaching to ground water (ButterbachBahl et al. 2013, Barta et al. 2017). Agricultural activities such as use of $\mathrm{N}$ fertilizers and animal manure are the main anthropogenic sources responsible for the atmospheric $\mathrm{N}_{2} \mathrm{O}$ increase (Bouwman et al. 2002, Davidson 2009). Greenhouse effect of $\mathrm{N}_{2} \mathrm{O}$ has an almost 300-fold greater potential than $\mathrm{CO}_{2}$ (Thomson et al. 2012). We are still far from fully understanding microbial regulation of the processes for nitrogen losses in agricultural production. It is now well recognized that microbial activities in soils are a major contributor to atmospheric loading of $\mathrm{N}_{2} \mathrm{O}$ (Snyder et al. 2009, Thomson et al. 2012). Similarly, $\mathrm{NO}_{3}{ }^{-}$, as the most mobile form of $\mathrm{N}$ in soil, leaches easily from the soil ecosystems and, therefore, has emerged as one of the most alarming and widespread contaminants of groundwater and surface water resources. The $\mathrm{NO}_{3}{ }^{-}$leaching usually originates from diffuse sources, such as intensive agriculture and unsewered sanitation in densely populated regions or point sources such as irrigation of land by sewage effluent. Fertilizer application and subsequent leaching from cropland is reported to have the highest contribution $(60 \%)$ toward $\mathrm{NO}_{3}{ }^{-}$leaching into the groundwater. Groundwater contamination by $\mathrm{NO}_{3}{ }^{-}$is a globally growing problem and more than 80 pounds of nitrogen per acre per year has been estimated leaching into groundwater underneath irrigated lands, usually as $\mathrm{NO}_{3}{ }^{-}$(Subbarao et al. 2006, Margalef-Marti et al. 2021).

\section{Conclusions}

Our study discovered significant effects of agricultural practices on soil microbial and $\mathrm{N}$ functional diversity compared with adjacent forest soils. Agricultural practices performed a negative effect on soil bacterial diversity and the diversity of denitrification nir $\mathrm{K}$ functional gene, whereas the relative abundance of a nitrification OTU was significantly increased by agricultural practice, suggesting the higher potential of $\mathrm{N}_{2} \mathrm{O}$ emission for greenhouse gas effects as well as the higher $\mathrm{NO}_{3}{ }^{-}$leaching rate for ground water contamination in crop than in forest soils. Soils are the foundation of a healthy ecosystem. Soil microbiomes play critical roles in regulating soil nutrient especially $\mathrm{N}$ cycling processes and contribute to climate change such as microbial-mediated $\mathrm{N}_{2} \mathrm{O}$ emission for global warming, $\mathrm{NO}_{3}{ }^{-}$leaching for underground water contamination, and mitigation of soilborne diseases for soil health. Clearly understanding the microbial diversity changes from forest transition to crop soils will offer great potential to gauge the health of soil ecosystems subjected to $\mathrm{N}_{2} \mathrm{O}$ emission for global warming and $\mathrm{NO}_{3}{ }^{-}$leaching for ground water contamination, as well as soil microbiomes and $\mathrm{N}$ forms to suppress soilborne diseases.

\section{Acknowledgements}

This research was supported by the funding from the Georgia Southern University Faculty Research Grant awarded to Dr. Tiehang Wu. We would like to thank Dr. Scott Harrison for assistance in using ABI 3500, and Genomics and Bioinformatics Cores at University of Georgia for Illumina sequencing analyses.

\section{References:}

Barta, J., K. Tahovska, H. Santruckova, and F. Oulehle. 2017. Microbial communities with distinct denitrification potential in spruce and beech soils differing in nitrate leaching. Scientific Reports 7 .

Bevivino, A., P. Paganin, G. Bacci, A. Florio, M. S. Pellicer, M. C. Papaleo, A. Mengoni, L. Ledda, R. Fani, A. Benedetti, and C. Dalmastri. 2014. Soil Bacterial Community Response to Differences in Agricultural Management along with Seasonal Changes in a Mediterranean Region. Plos One 9.

Bouwman, A. F., L. J. M. Boumans, and N. H. Batjes. 2002. Emissions of N2O and NO from fertilized fields: Summary of available measurement data. Global Biogeochemical Cycles 16 .

Burton, J., C. R. Chen, Z. H. Xu, and H. Ghadiri. 2010. Soil microbial biomass, activity and community composition in adjacent native and plantation forests of subtropical Australia. Journal of Soils and Sediments $10: 1267-1277$.

Butterbach-Bahl, K., E. M. Baggs, M. Dannenmann, R. Kiese, and S. Zechmeister-Boltenstern. 2013. Ni- 
trous oxide emissions from soils: how well do we understand the processes and their controls? Philosophical Transactions of the Royal Society B-Biological Sciences 368 .

Caporaso, J. G., J. Kuczynski, J. Stombaugh, K. Bittinger, F. D. Bushman, E. K. Costello, N. Fierer, A. G. Pena, J. K. Goodrich, J. I. Gordon, G. A. Huttley, S. T. Kelley, D. Knights, J. E. Koenig, R. E. Ley, C. A. Lozupone, D. McDonald, B. D. Muegge, M. Pirrung, J. Reeder, J. R. Sevinsky, P. J. Tumbaugh, W. A. Walters, J. Widmann, T. Yatsunenko, J. Zaneveld, and R. Knight. 2010. QIIME allows analysis of high-throughput community sequencing data. Nature Methods7 :335-336.

Cavigelli, M. A., and G. P. Robertson. 2000. The functional significance of denitrifier community composition in a terrestrial ecosystem. Ecology $81: 1402-1414$.

Cavigelli, M. A., and G. P. Robertson. 2001. Role of denitrifier diversity in rates of nitrous oxide consumption in a terrestrial ecosystem. Soil Biology \& Biochemistry 33 :297-310.

Chellemi, D. O., T. H. Wu, J. H. Graham, and G. Church. 2012. Biological Impact of Divergent Land Management Practices on Tomato Crop Health. Phytopathology 102 :597-608.

Daims, H., S. Lucker, and M. Wagner. 2016. A New Perspective on Microbes Formerly Known as NitriteOxidizing Bacteria. Trends in Microbiology24:699-712.

Davidson, E. A. 2009. The contribution of manure and fertilizer nitrogen to atmospheric nitrous oxide since 1860. Nature Geoscience 2 :659-662.

de Graaff, M. A., N. Hornslein, H. L. Throop, P. Kardol, and L. T. A. van Diepen. 2019. Effects of agricultural intensification on soil biodiversity and implications for ecosystem functioning: A meta-analysis. Advances in Agronomy, Vol 155155 :1-44.

Eichorst, S. A., J. A. Breznak, and T. M. Schmidt. 2007. Isolation and characterization of soil bacteria that define Teniglobus gen. nov., in the phylum Acidobacteria. Applied and Environmental Microbiology73 $: 2708-2717$.

Fierer, N., M. A. Bradford, and R. B. Jackson. 2007. Toward an ecological classification of soil bacteria. Ecology 88 : 1354-1364.

Fierer, N., J. A. Jackson, R. Vilgalys, and R. B. Jackson. 2005. Assessment of soil microbial community structure by use of taxon-specific quantitative PCR assays. Applied and Environmental Microbiology $\mathbf{7 1}$ :4117-4120.

Fierer, N., and R. B. Jackson. 2006. The diversity and biogeography of soil bacterial communities. Proceedings of the National Academy of Sciences of the United States of America 103 :626-631.

Gans, J., M. Wolinsky, and J. Dunbar. 2005. Computational improvements reveal great bacterial diversity and high metal toxicity in soil. Science $309: 1387-1390$.

Geisen, S., D. H. Wall, and W. H. van der Putten. 2019. Challenges and Opportunities for Soil Biodiversity in the Anthropocene. Current Biology 29 :R1036-R1044.

Goss-Souza, D., L. W. Mendes, C. D. Borges, J. L. M. Rodrigues, and S. M. Tsai. 2019. Amazon forest-toagriculture conversion alters rhizosphere microbiome composition while functions are kept. Fems Microbiology Ecology 95 .

Gu, Z. C., M. Wang, Y. Wang, L. X. Zhu, L. A. J. Mur, J. Hu, and S. W. Guo. 2020. Nitrate Stabilizes the Rhizospheric Fungal Community to Suppress Fusarium Wilt Disease in Cucumber. Molecular Plant-Microbe Interactions $33: 590-599$.

Huber, D. M., and R. D. Watson. 1974. Nitrogen Form and Plant Disease. Annual Review of Phytopathology $12: 139-165$. 
Jangid, K., M. A. Williams, A. J. Franzluebbers, J. S. Sanderlin, J. H. Reeves, M. B. Jenkins, D. M. Endale, D. C. Coleman, and W. B. Whitman. 2008. Relative impacts of land-use, management intensity and fertilization upon soil microbial community structure in agricultural systems. Soil Biology \& Biochemistry $40: 2843-2853$.

Jenkins, S. F., and C. W. Averre. 1986. Problems and Progress in Integrated Control of Southern Blight of Vegetables. Plant Disease70 :614-619.

Jha, P. B., J. S. Singh, and A. K. Kashyap. 1996. Dynamics of viable nitrifier community and nutrient availability in dry tropical forest habitat as affected by cultivation and soil texture. Plant and Soil180 :277-285.

Jones, R. T., M. S. Robeson, C. L. Lauber, M. Hamady, R. Knight, and N. Fierer. 2009. A comprehensive survey of soil acidobacterial diversity using pyrosequencing and clone library analyses. Isme Journal3 :442453.

Kielak, A. M., C. C. Barreto, G. A. Kowalchuk, J. A. van Veen, and E. E. Kuramae. 2016. The Ecology of Acidobacteria: Moving beyond Genes and Genomes. Frontiers in Microbiology 7 .

Kyveryga, P. M., A. M. Blackmer, J. W. Ellsworth, and R. Isla. 2004. Soil pH effects on nitrification of fall-applied anhydrous ammonia. Soil Science Society of America Journal 68 :545-551.

Lammel, D. R., K. Nusslein, C. E. P. Cerri, S. D. Veresoglou, and M. C. Rillig. 2021. Soil biota shift with land use change from pristine rainforest and Savannah (Cerrado) to agriculture in southern Amazonia. Molecular Ecology $30: 4899-4912$.

Lauber, C. L., M. Hamady, R. Knight, and N. Fierer. 2009. Pyrosequencing-Based Assessment of Soil pH as a Predictor of Soil Bacterial Community Structure at the Continental Scale. Applied and Environmental Microbiology 75 :5111-5120.

Le Roux, X., B. Schmid, F. Poly, R. L. Barnard, P. A. Niklaus, N. Guillaumaud, M. Habekost, Y. Oelmann, L. Philippot, J. F. Salles, M. Schloter, S. Steinbeiss, and A. Weigelt. 2013. Soil Environmental Conditions and Microbial Build-Up Mediate the Effect of Plant Diversity on Soil Nitrifying and Denitrifying Enzyme Activities in Temperate Grasslands. Plos One 8 .

Levy-Booth, D. J., C. E. Prescott, and S. J. Grayston. 2014. Microbial functional genes involved in nitrogen fixation, nitrification and denitrification in forest ecosystems. Soil Biology \& Biochemistry75 :11-25.

Li, W. J., L. M. Jiang, Y. Zhang, D. X. Teng, H. F. Wang, J. L. Wang, and G. H. Lv. 2021. Structure and driving factors of the soil microbial community associated with Alhagi sparsifolia in an arid desert. Plos One16 .

Li, Z. L., Z. Q. Zeng, D. S. Tian, J. S. Wang, Z. Fu, F. Y. Zhang, R. Y. Zhang, W. N. Chen, Y. Q. Luo, and S. L. Niu. 2020. Global patterns and controlling factors of soil nitrification rate. Global Change Biology26 :4147-4157.

Margalef-Marti, R., A. Llovet, R. Carrey, A. Ribas, X. Domene, S. Mattana, J. Chin-Pampillo, C. Mondini, J. M. Alcaniz, A. Soler, and N. Otero. 2021. Impact of fertilization with pig slurry on the isotopic composition of nitrate retained in soil and leached to groundwater in agricultural areas. Applied Geochemistry 125 .

Milner, H., P. S. Ji, M. Sabula, and T. H. Wu. 2019. Quantitative polymerase chain reaction (Q-PCR) and fluorescent in situ hybridization (FISH) detection of soilborne pathogen Sclerotium rolfsii. Applied Soil Ecology 136 :86-92.

Nelson, D. W. 1983. Determination of Ammonium in Kcl Extracts of Soils by the Salicylate Method. Communications in Soil Science and Plant Analysis 14 :1051-1062.

Nugroho, R. A., W. F. M. Roling, A. M. Laverman, and H. A. Verhoef. 2007. Low nitrification rates in acid scots pine forest soils are due to pH-related factors. Microbial Ecology 53 :89-97. 
Ouyang, Y., S. E. Evans, M. L. Friesen, and L. K. Tiemann. 2018. Effect of nitrogen fertilization on the abundance of nitrogen cycling genes in agricultural soils: A meta-analysis of field studies. Soil Biology \& Biochemistry 127 :71-78.

Pihlatie, M., E. Syvasalo, A. Simojoki, M. Esala, and K. Regina. 2004. Contribution of nitrification and denitrification to $\mathrm{N} 2 \mathrm{O}$ production in peat, clay and loamy sand soils under different soil moisture conditions. Nutrient Cycling in Agroecosystems 70 :135-141.

Rodrigues, J. L. M., V. H. Pellizari, R. Mueller, K. Baek, E. D. Jesus, F. S. Paula, B. Mirza, G. S. Hamaoui, S. M. Tsai, B. Feigl, J. M. Tiedje, B. J. M. Bohannan, and K. Nusslein. 2013. Conversion of the Amazon rainforest to agriculture results in biotic homogenization of soil bacterial communities. Proceedings of the National Academy of Sciences of the United States of America 110 :988-993.

Rousk, J., E. Baath, P. C. Brookes, C. L. Lauber, C. Lozupone, J. G. Caporaso, R. Knight, and N. Fierer. 2010. Soil bacterial and fungal communities across a pH gradient in an arable soil. Isme Journal4:1340-1351.

Schmidt, I., O. Sliekers, M. Schmid, I. Cirpus, M. Strous, E. Bock, J. G. Kuenen, and M. S. M. Jetten. 2002. Aerobic and anaerobic ammonia oxidizing bacteria competitors or natural partners? Fems Microbiology Ecology 39 :175-181.

Senbayram, M., R. Chen, A. Budai, L. Bakken, and K. Dittert. 2012. N2O emission and the N2O/(N2O + $\mathrm{N}-2$ ) product ratio of denitrification as controlled by available carbon substrates and nitrate concentrations. Agriculture Ecosystems \& Environment $147: 4-12$.

Snyder, C. S., T. W. Bruulsema, T. L. Jensen, and P. E. Fixen. 2009. Review of greenhouse gas emissions from crop production systems and fertilizer management effects. Agriculture Ecosystems \& Environment133 $: 247-266$.

Song, X. T., X. T. Ju, C. F. E. Topp, and R. M. Rees. 2019. Oxygen Regulates Nitrous Oxide Production Directly in Agricultural Soils. Environmental Science \& Technology 53 :12539-12547.

Subbarao, G. V., O. Ito, K. L. Sahrawat, W. L. Berry, K. Nakahara, T. Ishikawa, T. Watanabe, K. Suenaga, M. Rondon, and I. M. Rao. 2006. Scope and strategies for regulation of nitrification in agricultural systemschallenges and opportunities. Critical Reviews in Plant Sciences25 :303-335.

Szukics, U., E. Hackl, S. Zechmeister-Boltenstern, and A. Sessitsch. 2012. Rapid and dissimilar response of ammonia oxidizing archaea and bacteria to nitrogen and water amendment in two temperate forest soils. Microbiological Research $167: 103-109$.

Thomson, A. J., G. Giannopoulos, J. Pretty, E. M. Baggs, and D. J. Richardson. 2012. Biological sources and sinks of nitrous oxide and strategies to mitigate emissions. Philosophical Transactions of the Royal Society B-Biological Sciences 367 :1157-1168.

Torsvik, V. L., and J. Goksoyr. 1978. Determination of Bacterial DNA in Soil. Soil Biology \& Biochemistry $10: 7-12$.

Upchurch, R., C. Y. Chi, K. Everett, G. Dyszynski, D. C. Coleman, and W. B. Whitman. 2008. Differences in the composition and diversity of bacterial communities from agricultural and forest soils. Soil Biology \& Biochemistry 40 :1294-1305.

Vanbruggen, A. H. C. 1995. Plant-Disease Severity in High-Input Compared to Reduced-Input and Organic Farming Systems. Plant Disease 79 :976-984.

Wu, T., D. O. Chellemi, J. H. Graham, K. J. Martin, and E. N. Rosskopf. 2008. Comparison of soil bacterial communities under diverse agricultural land management and crop production practices. Microbial Ecology $55: 293-310$.

Wu, T. H., A. Gray, G. Liu, H. Kaminski, B. O. Efa, and D. P. Aubrey. 2020. Groundwater Depth Overrides Tree-Species Effects on the Structure of Soil Microbial Communities Involved in Nitrogen Cycling in 
Plantation Forests. Forests 11 .

Wu, T. H., H. Milner, J. C. Diaz-Perez, and P. S. Ji. 2015. Effects of soil management practices on soil microbial communities and development of southern blight in vegetable production. Applied Soil Ecology $\mathbf{9 1}$ :58-67.

Table 1. Soil chemical characteristics and the significance (p-value) of statistical analysis under different vegetation types and locations. Means $\pm \mathrm{SE}(\mathrm{n}=3)$ are presented. Means for main effects followed by different letters are significantly different at $\mathrm{p}<0.05$.

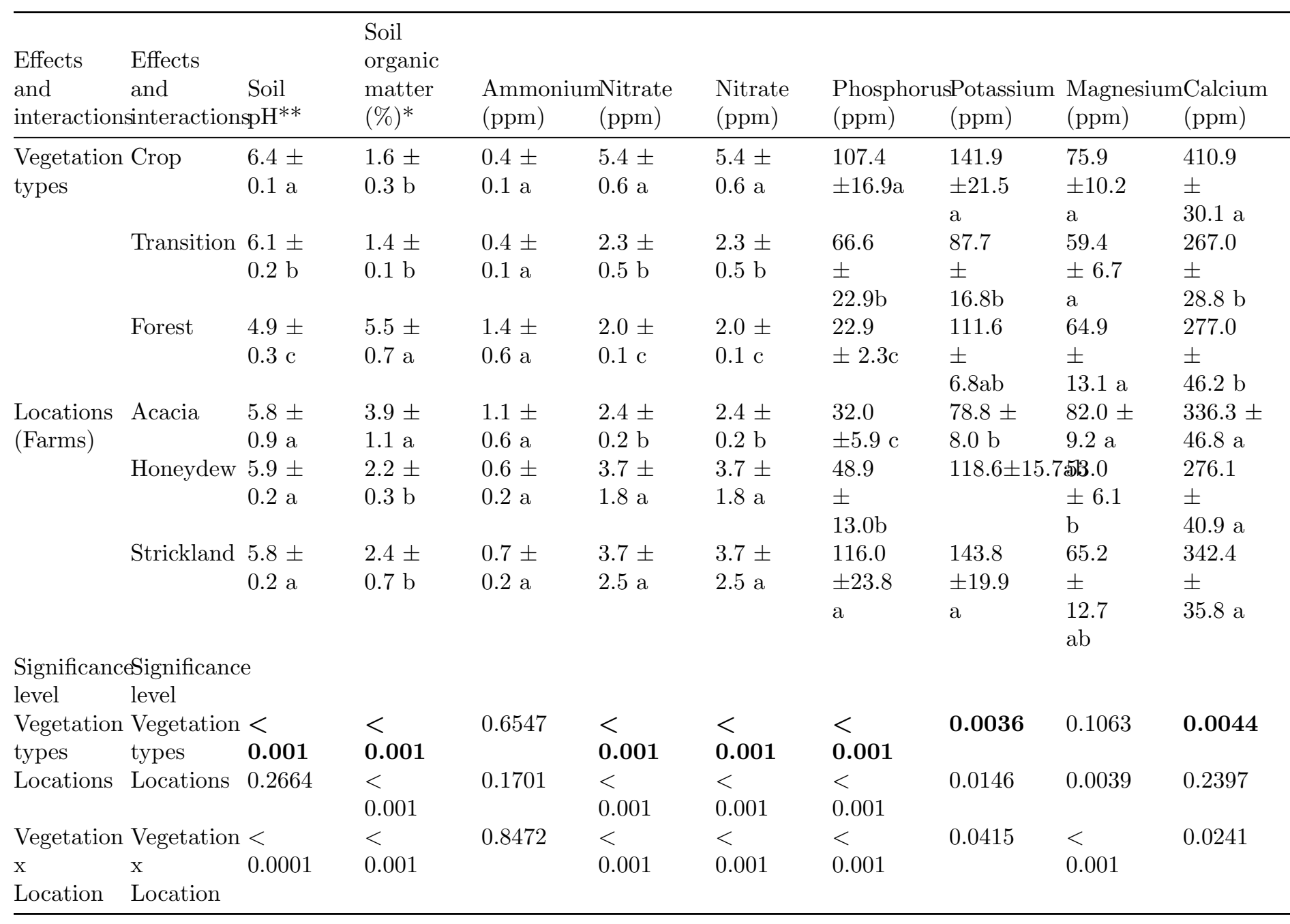

* Soil organic matter (\%) was determined as soil organic carbon \% using Walkley-Black Method.

** The bold fonts indicate significant at $\mathrm{p}<0.05$ for the vegetation types.

Table 2. Bacterial diversity based on Illumina sequences of bacteria

\begin{tabular}{|c|c|c|c|c|}
\hline Vegetation types & Diversity Indices $\pm \mathrm{SE}$ & Diversity Indices $\pm \mathrm{SE}$ & Diversity Indices $\pm \mathrm{SE}$ & Divers \\
\hline & Richness & Richness & Evenness (J') & Shann \\
\hline More disturbed crop land & More disturbed crop land & $479 \pm 101 \mathrm{~b}$ & $0.84 \pm 0.02 \mathrm{a}$ & $4.9 \pm$ \\
\hline Moderate disturbed transition land & $715 \pm 111 \mathrm{ab}$ & $715 \pm 111 \mathrm{ab}$ & $0.84 \pm 0.03 \mathrm{a}$ & $5.1 \pm$ \\
\hline
\end{tabular}




\begin{tabular}{|c|c|c|c|c|}
\hline Vegetation types & Diversity Indices $\pm \mathrm{SE}$ & Diversity Indices $\pm \mathrm{SE}$ & Diversity Indices $\pm \mathrm{SE}$ & Divers \\
\hline $\begin{array}{l}\text { Less disturbed forest land } \\
\text { Significance level }\end{array}$ & $878 \pm 126$ a & $878 \pm 126 a$ & $0.87 \pm 0.04 \mathrm{a}$ & $5.5 \pm$ \\
\hline Vegetation types & $0.04^{*}$ & $0.04^{*}$ & 0.35 & $0.02 *$ \\
\hline Locations & 0.12 & 0.12 & 0.61 & 0.27 \\
\hline Vegetation $\mathrm{x}$ Location & 0.45 & 0.45 & 0.54 & 0.11 \\
\hline
\end{tabular}

Table 3. Similarity percentage breakdown (SIMPER) analysis of soil bacterial contribution $\%$ to each vegetation based upon Illumina sequencing data.

Vegetation types

\begin{tabular}{lll}
\hline More disturbed crop & More disturbed crop & Moderate disturbed transition \\
OTU/"Species" & $\%$ & OTU/"Species" \\
uncultured_bacterium_f_Xanthobacteraceae (OTU1) & 12.4 & uncultured_bacterium_f_Xanthobacteraceae \\
uncultured_bacterium_f_ Nitrobacteraceae (OTU4) & 4.9 & uncultured_bacterium_f_Xanthobacteraceae \\
uncultured_bacterium_f_ Xanthobacteraceae (OTU2) & 4.5 & uncultured_bacterium_O_Acidobacteriales (C \\
uncultured_bacterium_f_ Methyloligellaceae (OTU16) & 2.2 & uncultured_bacterium_f_Xanthobacteraceae \\
uncultured_bacterium_f_Xanthobacteraceae (OTU91) & 1.8 & uncultured_bacterium_f_ Nitrobacteraceae (C \\
Cumulative \% & 25.9 &
\end{tabular}

Table 4. Relative abundance of AOB amo A, and nir K gene under highly disturbed crop (C), moderate disturbed transition $(\mathrm{T})$, and less disturbed native forest $(\mathrm{F})$ fields from three locations at the coastal plain of Georgia, USA.

\begin{tabular}{llll}
\hline Vegetation types & Vegetation types & Vegetation types & Relative abund \\
\hline & AOB $a m o \mathrm{~A} 10^{5}$ gene copy soil $^{-1}$ & AOB $a m o \mathrm{~A} 10^{5}$ gene copy soil $^{-1}$ & AOB $a m o \mathrm{~A} 10$ \\
More disturbed crop soil & $3.1 \pm 0.4 \mathrm{a}$ & $3.1 \pm 0.4 \mathrm{a}$ & $3.1 \pm 0.4 \mathrm{a}$ \\
Moderate disturbed transition soil & Moderate disturbed transition soil & $1.4 \pm 0.3 \mathrm{~b}$ & $1.4 \pm 0.3 \mathrm{~b}$ \\
Less disturbed forest soil & Less disturbed forest soil & Less disturbed forest soil & Less disturbed \\
Significance level & Significance level & Significance level & Significance 1 \\
Vegetation types & Vegetation types & Vegetation types & Vegetation typ \\
Locations & Locations & Locations & Locations \\
Vegetation x Location & Vegetation x Location & Vegetation x Location & Vegetation x L \\
\hline
\end{tabular}

Table 5. Richness, evenness and Shannon diversity of nir K gene under highly disturbed crop (C), moderate disturbed transition $(\mathrm{T})$, and less disturbed native forest $(\mathrm{F})$ fields from three locations at the coastal plain of Georgia, USA.

\begin{tabular}{llll}
\hline Vegetation types & Diversity Indices \pm SE & Diversity Indices \pm SE & Diversity Indices \pm SE \\
\hline & Richness & Evenness $\left(\mathrm{J}^{\prime}\right)$ & Shannon Diversity $\left(\mathrm{H}^{\prime}\right)$ \\
More disturbed crop soil & $3.2 \pm 0.4 \mathrm{~b}$ & $0.71 \pm 0.05 \mathrm{a}$ & $0.81 \pm 0.13 \mathrm{~b}$ \\
Moderate disturbed transition soil & $4.4 \pm 0.9 \mathrm{~b}$ & $0.77 \pm 0.03 \mathrm{a}$ & $1.07 \pm 0.18 \mathrm{~b}$ \\
Less disturbed forest soil & $6.2 \pm 0.5 \mathrm{a}$ & $0.79 \pm 0.03 \mathrm{a}$ & $1.42 \pm 0.07 \mathrm{a}$ \\
Significance level & & & \\
Vegetation types & $\mathbf{0 . 0 0 5 6 *}$ & 0.4796 & $\mathbf{0 . 0 0 4 8 ^ { * }}$ \\
Locations & 0.3163 & 0.2574 & 0.1413
\end{tabular}




\begin{tabular}{llll}
\hline Vegetation types & Diversity Indices \pm SE & Diversity Indices \pm SE & Diversity Indices \pm SE \\
\hline Vegetation x Location & 0.0537 & 0.0513 & $\mathbf{0 . 0 3 3 0 *}$ \\
\hline
\end{tabular}

Figure captions:

Figure 1. Relative abundance (\%) of bacteria at the level of phyla obtained by Illumina sequences from soil samples of different vegetation types including crop $(\mathrm{C})$, transition $(\mathrm{T})$, and forest $(\mathrm{F})$ soils in Acacia $(\mathrm{A})$, Honeydew $(\mathrm{H})$, and Strickland $(\mathrm{S})$ farms of the coastal region of Georgia, USA.

Figure 2. Relative abundance (\%) of Acidiobacteria and Proteobacteria from different vegetation types of crop, transition, and forest soils by Illumina sequences.

Figure 3. A) Cluster and B) NMDS analysis of bacterial communities from different vegetation types of crop, transition and forest soils based upon Illumina sequencing data.

Figure 4. The relative abundance (\%) of A) uncultured bacteria belonging to Acidobacteriales (OTU5) and Acidipila sp. (OTU8), and B) an uncultured bacterium (OTU4) belonging to Nitrobacteraceae at each vegetation types based upon Illumina sequencing data.

Figure 5. A) DGGE profiles and B) cluster analysis of nir K gene under highly disturbed crop (C), moderate disturbed transition $(\mathrm{T})$, and less disturbed native forest $(\mathrm{F})$ fields from three locations in Acacia (A), Honeydew $(\mathrm{H})$, and Strickland $(\mathrm{S})$ farms at the coastal plain of Georgia.

Figure 1.

\section{Hosted file}

image1.emf available at https://authorea.com/users/446405/articles/545648-agriculturalpractice-negatively-affects-soil-microbial-diversity-and-nitrogen-functional-genescomparing-to-adjacent-native-forest-soils

Figure 2

\section{Hosted file}

image2.emf available at https://authorea.com/users/446405/articles/545648-agriculturalpractice-negatively-affects-soil-microbial-diversity-and-nitrogen-functional-genescomparing-to-adjacent-native-forest-soils

Figure 3

A.

\section{Hosted file}

image3.emf available at https://authorea.com/users/446405/articles/545648-agriculturalpractice-negatively-affects-soil-microbial-diversity-and-nitrogen-functional-genescomparing-to-adjacent-native-forest-soils

B.

\section{Hosted file}

image4.emf available at https://authorea.com/users/446405/articles/545648-agriculturalpractice-negatively-affects-soil-microbial-diversity-and-nitrogen-functional-genescomparing-to-adjacent-native-forest-soils

Figure 4 .

A. 


\section{Hosted file}

image5.emf available at https://authorea.com/users/446405/articles/545648-agriculturalpractice-negatively-affects-soil-microbial-diversity-and-nitrogen-functional-genescomparing-to-adjacent-native-forest-soils

B.

\section{Hosted file}

image6.emf available at https://authorea.com/users/446405/articles/545648-agriculturalpractice-negatively-affects-soil-microbial-diversity-and-nitrogen-functional-genescomparing-to-adjacent-native-forest-soils

Figure 5

A.

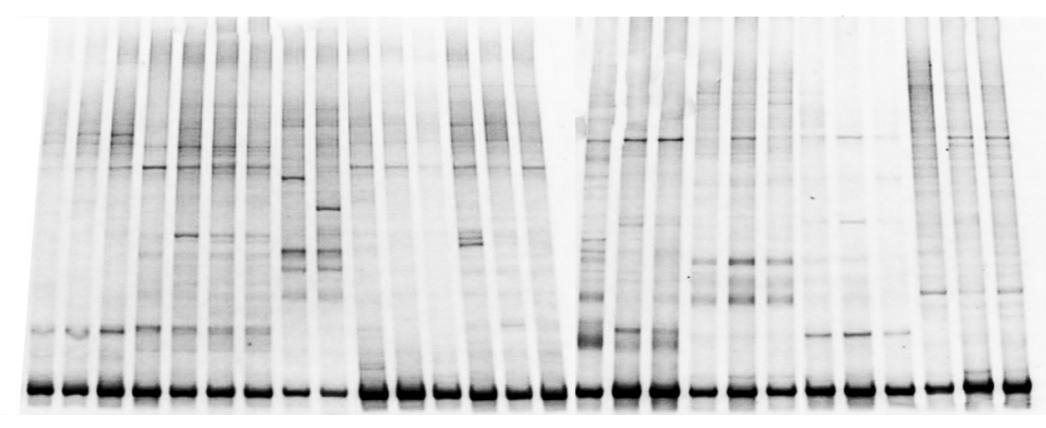

B.

\section{Hosted file}

image8.emf available at https://authorea.com/users/446405/articles/545648-agriculturalpractice-negatively-affects-soil-microbial-diversity-and-nitrogen-functional-genescomparing-to-adjacent-native-forest-soils 